\title{
The activity of the intestinal wall of the cow in sodium homeostasis
}

\author{
J. A. RENKEMA, TATSUDO SENSHU, BLANCHE D. E. GAILLARD and \\ E. BROUWER
}

Laboratory of Animal Physiology of the Agricultural University 'at Wageningen, The Netherlands

\begin{abstract}
Summary
Two heifers and one milch-cow were fed low sodium rations, without and with extra sodium addition.

In the faeces, the faecal juice and the urine distinctly lower sodium concentrations were found in the low sodium periods than in the high sodium periods. In these low sodium periods the potassium concentrations in the faeces and in the faecal juice were distinctly higher than in the high sodium periods. At the same time there was a small but significant decrease of the sodium concentration in the milk. No significant differences were found in the dry matter content of the faeces and in the osmotic pressure of the faecal juice. This osmotic pressure was always $1 / 2$ to $2 / 3$ of that in the blood.

It is concluded that, besides the kidneys, the gut plays an important role in regulating sodium metabolism (sodium homeostasis) of the cow on low sodium rations.
\end{abstract}

\section{Introduction}

It is well known that the kidney is the principal organ regulating sodium retention and excretion in order to maintain a constant sodium level in the blood and tissues (sodium homeostasis).

Concerning the sodium absorption in the gut it also has been shown that the behaviour of the intestinal wall is not merely passive so that there would be a tendency to equal concentrations of sodium in the intestinal and faecal juices on the one hand and in the blood plasma on the other hand, as formerly was believed. In cows, for instance, VAN WEERDEN $(1959,1961)$ showed that in the lower part of the small intestine and in the large intestine, sodium absorption takes place against a considerable concentration gradient so that relatively little sodium is lost with the faeces. This makes that the cow can subsist on surprisingly small quantities of sodium in the feed. VAN WEERDEN (1959) stressed the importance of this fact because, ordinarily, pasture and other cattle feeds are very poor in sodium.

It seemed important to examine whether the final concentration of the sodium in the faecal juice is always the same or whether it is dependent on the amount of sodium in the feed; in other words: does the intestinal wall take part in establishing sodium homeostasis, and, if so, to what extent in comparison with the kidney?

Received for publication 24th October, 1961. 


\section{Literature}

The existence of sodium absorption from the intestinal tract against a concentration gradient has been demonstrated with laboratory animals such as rats, dogs and rabbits and also with humans. FIELD et al. (1954 a) found that the sodium concentration in the normal contents of the small intestine of dogs is nearly the same as that of the blood. VISSCHER and many others found that the lower part of the small intestine is able to perform an active absorption of sodium against a concentration gradient (VISSCHER et al., 1945; Visscher and RoePKe, 1945; CURRAN and Solomon, 1957; MCHARDY and Parsons, 1957). Similar facts have been found with the colon (EMERSON et al., 1954; Ross and SPENCER, 1954; Field et al., 1954 b, 1955 ; SPENCER et al., 1954; CuRran and Schwartz, 1960). Consequently, the sodium concentration in the faeces is much lower than that of the blood (Elkinton and Danowski, 1955; Field et al., $1954 \mathrm{~b}, 1955)$.

In the cow the problem might be more complicated, because the faecal juice is always hypotonic as compared with the blood (Brouwer and VAN WEERDEN, 1956). VAN WEERDEN $(1959,1961)$ showed that in this species the absorption takes place not only against a sodium concentration gradient but also against a gradient of the osmotic pressure.

With laboratory animals and human subjects it has been known that this specific sodium absorption works more efficiently when sodium intake is lower than normal (EMERSON et al., 1954; Field et al., 1954 a, 1955; SPEnCER et al., 1954; Ross and SPENCER, 1954). As far as we know such observations have not yet been made with cows.

\section{Experimental}

In a preliminary experiment some indications were found that increase in sodium content of the ration results in a distinct increase in sodium contents of the faecal press juice. This experiment was however not decisive because the increase in the sodium content of the urine was only very slight. Therefore in further experiments two heifers (EXPERIMENT I) and one milch-cow (EXPERIMENT II) were given sodium poor rations containing only $2,7-5,3 \mathrm{~g}$ sodium per day per animal. In a second period the same rations were fed but in addition $100 \mathrm{~g}$ of sodiumchloride with about $40 \mathrm{~g}$ of sodium per day per animal was added to the concentrates. Finally the animals received again the sodium poor rations. The basal rations are shown in TABLE 1 .

TABLE 1. Basal rations

\begin{tabular}{|c|c|c|c|}
\hline \multicolumn{3}{|c|}{ EXPERIMENT I } & EXPERIMENT II \\
\hline Days after beginning & $\ldots \quad 1$ to 58 & 59 to 93 & Days after beginning \\
\hline Rye straw & $4,0 \mathrm{~kg}$ & $4,0 \mathrm{~kg}$ & Rye straw \\
\hline Hay $\ldots$. & . $2,0 \quad$ " & $2,0 \quad$, & Hay $\ldots \ldots \ldots \ldots \ldots, \quad 3,0$, \\
\hline Maize meal & . 2,0 & $2,8 *$ & Potatoes $\ldots .$. \\
\hline Linseed meal & $\cdots \quad 0,5$ & $0,7 *$ & Mixed concentrates \\
\hline $\mathrm{CaCO}_{3} \ldots \ldots$ & $\ldots \ldots, 0,03$ & $0,03 "$ & $\mathrm{CaCO}_{3} \quad \ldots \ldots \ldots$ \\
\hline $\begin{array}{l}\mathrm{Na} \text { in the ration } \\
\mathrm{K} \text { in the ration }\end{array}$ & $\begin{array}{r}2,7 \text { to } 3,0 \mathrm{~g} \\
96,7 \text { to } 99,1 \mathrm{~g}\end{array}$ & $\begin{aligned} 2,8 \mathrm{~g} \\
100,8 \mathrm{~g}\end{aligned}$ & $\begin{array}{lr}\mathrm{Na} \text { in the ration } & 5,3 \text { to } 7,2 \mathrm{~g} \\
\mathrm{~K} \text { in the ration } & 169,8 \text { to } 179,4 \mathrm{~g}\end{array}$ \\
\hline
\end{tabular}

* Addition for pregnancy. 
Samples of faeces, urine and milk (milk was produced in EXPERIMENT II only) were taken about every 3-5 days. In EXPERIMENT II milk, faeces and urine were weighed daily.

Determinations were made of dry matter in the faeces and of sodium and potassium in faeces, urine and milk. Moreover, press-juice (ultrafiltrate) was obtained by pressing the faeces in a membrane press with cellophane and with the aid of nitrogen gas under pressure of 10 atmospheres (VAN WEERDEN, 1959). In this juice sodium, potassium and osmotic pressure were determined.

The determinations of sodium and potassium were made by flame photometer in the solution of the ashed samples. The osmotic pressure was determined by freezing point depression using a BECKMANN apparatus.

\section{Results and discussion}

The results of the experiments are shown in TABLE 2. The results of the second low sodium period in EXPERIMENT II are however omitted because the sodium content of the ration was higher than expected.

TABLE 2. Experimental results

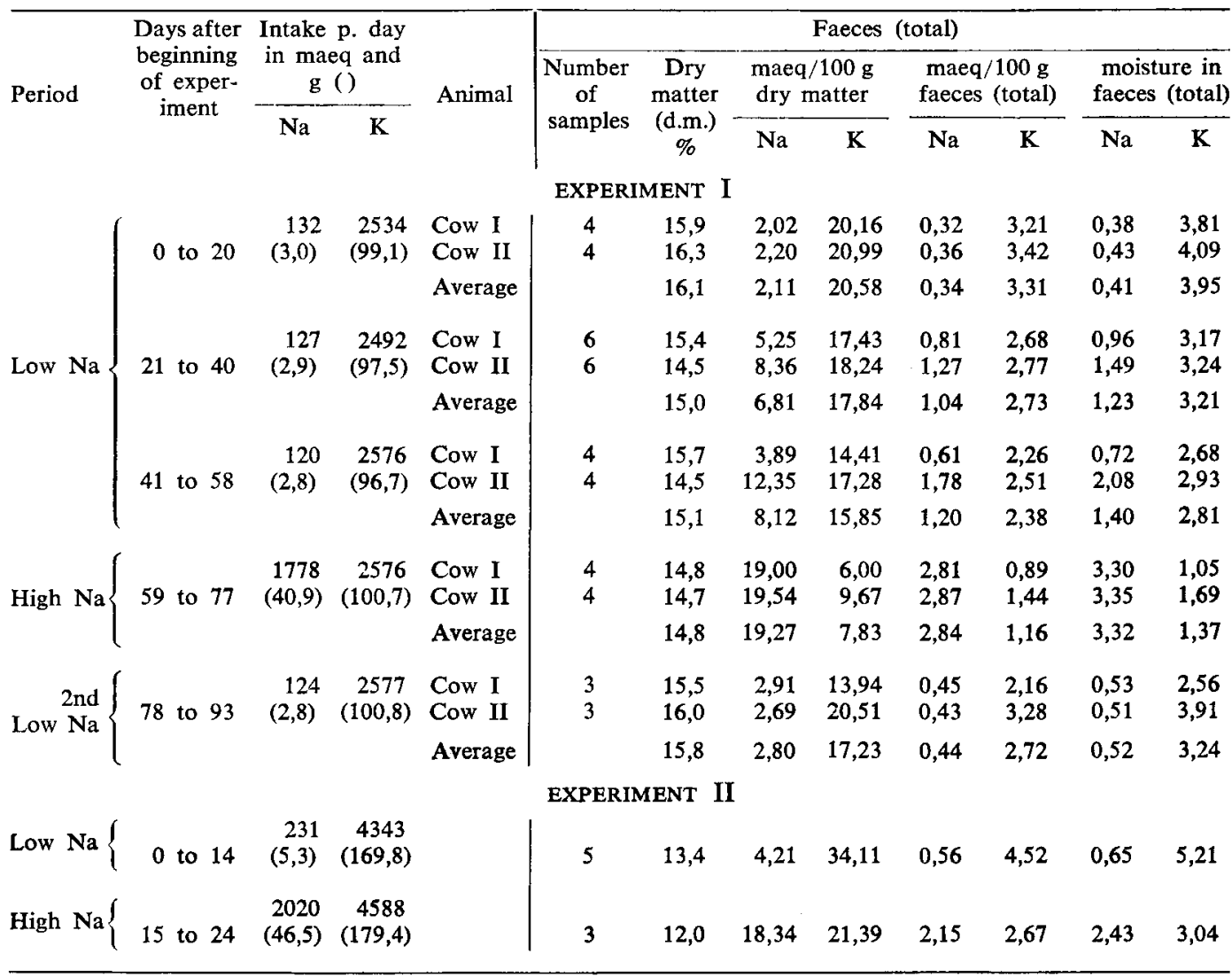


With regard to the dry matter content of the faeces, no significant difference was found between high sodium and low sodium periods.

During the low sodium periods, the sodium concentrations in the whole faeces, in the faecal juice and in the urine were distinctly lower than in the high sodium periods. There was only a small but significant decrease of sodium concentration in the milk $(P<0,01)$.

During the first week of the low sodium period the gut apparently adapted itself to the low $\mathrm{Na}$ intake. After this week the $\mathrm{Na}$ concentration in the press juice remained at an almost constant level. The adaptation of the kidneys was achieved within two days.

In both experiments the potassium concentrations in the whole faeces and in the faecal juice were in the low sodium periods distinctly higher than in the high sodium period. In EXPERIMENT I the potassium concentration in the urine also was higher during the low sodium periods.

The freezing point depression of the faecal juice was always within the same range as has been found by VAN WEERDEN (1959), thus, much lower than that of the

\begin{tabular}{|c|c|c|c|c|c|c|c|c|c|c|}
\hline \multicolumn{5}{|c|}{ Faecal juice } & \multicolumn{3}{|c|}{ Urine } & \multicolumn{3}{|c|}{ Milk } \\
\hline \multirow{2}{*}{$\begin{array}{l}\text { Number } \\
\text { of } \\
\text { samples }\end{array}$} & \multicolumn{2}{|c|}{ maeq $/ 100 \mathrm{ml}$} & \multirow{2}{*}{$\begin{array}{l}\text { Number } \\
\text { of } \\
\text { samples }\end{array}$} & \multirow{2}{*}{$\begin{array}{l}\text { Freezing } \\
\text { point de- } \\
\text { pression }\end{array}$} & \multirow{2}{*}{$\begin{array}{c}\text { Number } \\
\text { of } \\
\text { samples }\end{array}$} & \multicolumn{2}{|c|}{ maeq $/ 100 \mathrm{ml}$} & \multirow{2}{*}{$\begin{array}{c}\text { Number } \\
\text { of } \\
\text { samples }\end{array}$} & \multicolumn{2}{|c|}{$\mathrm{maeq} / 100 \mathrm{ml}$} \\
\hline & $\mathrm{Na}$ & $\mathbf{K}$ & & & & $\mathrm{Na}$ & $\mathbf{K}$ & & $\mathrm{Na}$ & $\mathbf{K}$ \\
\hline \multicolumn{11}{|c|}{ EXPERIMENT I } \\
\hline \multirow{3}{*}{$\begin{array}{l}3 \\
3\end{array}$} & 0,32 & 3,03 & & & 1 & 0,07 & 42,4 & & & \\
\hline & 0,29 & 3,20 & & & 2 & 0,07 & 42,6 & & & \\
\hline & 0,31 & 3,12 & & & & 0,07 & 42,5 & & & \\
\hline \multirow{3}{*}{$\begin{array}{l}6 \\
6\end{array}$} & 0,70 & 2,78 & 1 & 0,280 & 4 & 0,09 & 52,0 & & & \\
\hline & 1,07 & 2,70 & & & 2 & 3,07 & 31,8 & & & \\
\hline & 0,88 & 2,74 & & & & 1,58 & 41,9 & & & \\
\hline \multirow{3}{*}{$\begin{array}{l}4 \\
4\end{array}$} & 0,95 & 2,57 & 1 & 0,257 & 3 & 0,80 & 35,0 & & & \\
\hline & 2,15 & 2,75 & 1 & 0,300 & 3 & 2,74 & 30,4 & & & \\
\hline & 1,55 & 2,66 & & 0,278 & & 1,77 & 32,7 & & & \\
\hline \multirow{3}{*}{$\begin{array}{l}4 \\
4\end{array}$} & 3,63 & 1,71 & 4 & 0,328 & 4 & 15,43 & 25,1 & & & \\
\hline & 4,15 & 1,47 & 4 & 0,347 & 4 & 14,28 & 16,4 & & & \\
\hline & 3,89 & 1,59 & & 0,338 & & 14,86 & 20,8 & & & \\
\hline \multirow{3}{*}{$\begin{array}{l}3 \\
3\end{array}$} & 0,53 & 2,17 & 2 & 0,366 & 3 & 0.78 & 42.7 & & & \\
\hline & 0,56 & 3,67 & 3 & 0,346 & 3 & 0,30 & 35,1 & & & \\
\hline & 0,55 & 2,92 & & 0,356 & & 0,54 & 38,8 & & & \\
\hline \multicolumn{11}{|c|}{ EXPERIMENT II } \\
\hline 5 & 0,53 & 3,83 & 5 & 0,329 & 5 & 0,18 & 21,3 & 5 & 1,49 & 2,80 \\
\hline 3 & 2,24 & 2,78 & 3 & 0,325 & 3 & 4,26 & 24,7 & 3 & 1,69 & 2,76 \\
\hline
\end{tabular}


blood. There was in the juice no significant difference in the freezing point depression between the high sodium and the low sodium periods. Therefore, the above mentioned increase of potassium concentration in the low sodium periods can be supposed to be produced by a substitution of sodium by potassium, the former being selectively absorbed from the intestinal contents. In dogs such a substitution already has been found by Field et al. (1955) and in human subjects by SPENCER et al. (1954) by administration of cation exchange resins.

In EXPERIMENT II with a milch-cow the daily excretion of faeces was $34-35 \mathrm{~kg}$ per day. This big amount is presumably due to the $5 \mathrm{~kg}$ of straw the animal consumed and also to the low dry matter content of the faeces. In the high sodium period the sodium intake was about $46 \mathrm{~g}$ a day, which certainly is not excessive. The name moderate sodium period might have been used in stead of high sodium period. The total $\mathrm{Na}$ content of the faeces in this period was $2,15 \mathrm{maeq} / 100 \mathrm{~g}$. The $\mathrm{Na}$ content of the faecal juice was $2,24 \mathrm{maeq} / 100 \mathrm{ml}$. This value is about the same as the average $\mathrm{Na}$ concentration in faecal press juice reported by vaN WEERDEN (1959, 1961). The total excretion of $\mathrm{Na}$ in the faeces can be calculated to be : $35 \times 10 \times 2,15=752$ maeq $(17,3 \mathrm{~g})$ a day.

In the low sodium period of the same experiment the $\mathrm{Na}$ concentration in the faeces was only $0,56 \mathrm{maeq} / 100 \mathrm{~g}$. The total excretion of $\mathrm{Na}$ with the faeces amounted therefore to $35 \times 10 \times 0,56=196$ maeq $(4,5 \mathrm{~g})$ a day. Consequently, $752-$ $196=556$ maeq $(12,8 \mathrm{~g}) \mathrm{Na}$ was saved from being excreted. During the whole low sodium period the $\mathrm{Na}$ excretion with the faeces was therefore about $1 / 4$ as compared with the high (moderate) sodium period. After a week of adaptation of the gut to the low $\mathrm{Na}$ intake, the $\mathrm{Na}$ concentration in the press juices remained at an almost constant level of only 0,20 maeq/ $100 \mathrm{ml}$ or less. The $\mathrm{Na}$ excretion with the faeces can thus decrease to $1 / 10$ of its normal level of about 2 maeq $/ 100 \mathrm{ml}$ press juice. In this case the sodium was reabsorbed from the intestinal contents against a 75 times higher concentration in the blood.

These figures are not very much smaller than those referring to the absorption of sodium by the kidney tubules. In the urine however the $\mathrm{Na}$ concentration went still further down than in the faecal press juice and decreased until a level of 0,07 maeq $/ 100 \mathrm{ml}$ as compared with $0,20 \mathrm{maeq} / 100 \mathrm{ml}$ in the faecal juice. On the other hand, in the high sodium period the $\mathrm{Na}$ concentration in the urine was much higher than in the faeces.

In the high sodium period of EXPERIMENT II the average $\mathrm{Na}$ concentration in the urine was $4,26 \mathrm{maeq} / 100 \mathrm{ml}$ and in the low sodium period $0,18 \mathrm{maeq} / 100 \mathrm{ml}$. The daily quantity of urine could not be weighed accurately. In both periods it amounted to about $15 \mathrm{~kg}$ per day. Therefore, in the low sodium period about $15 \times 10 \times$ $4,26-15 \times 10 \times 0,18=612$ maeq $(14,1 \mathrm{~g}) \mathrm{Na} /$ day was saved from being excreted with the urine. As already has been mentioned before, we found with the faeces a saving of 556 maeq $(12,8 \mathrm{~g}) \mathrm{Na} /$ day. Thus, although the $\mathrm{Na}$ concentration in the urine decreased quicker and more than in the faeces, the total $\mathrm{Na}$ decrease in faeces and urine was about the same owing to the larger amount of faeces excreted per day.

From these experiments it appeared that, besides the kidneys, the gut plays an important role in the regulation of the sodium metabolism of the cow on low sodium rations. 
THE ACTIVITY OF THE INTESTINAL WALL OF THE COW IN HOMEOSTATIS

\section{REFERE N C ES}

Brouwer, E., and E. J. VAN WEERden

Curran, P. F., and

A. K. Solomon

Curran, P. F., and G. F. SCHWARTZ

ELKINTON, J. R., and T. S. DANOWSKI

EMERSON Jr, K., S. S.

1956 Nature. 178, p. 211.

1957 J. Gen. Physiol. 41, 143-168.

1959 J. Gen. Physiol. 43, 555-571.

1955 The Body-Fluids. Williams \& Wilkins, Baltimore.

1954 Ann. N.Y. Acad. Sci. 57, 280-290.

KAHN and D. JENKINS

FIELD Jr, H., R. E.

1954a Amer. J. Physiol. 179, 477-480.

DaIley, R. S. Boyd and L. SwELL

Field Jr, H., L. Swell,

D. F. FLICK and

R. E. DaILEY

FIELD Jr, H., L. SWELl,

R. E. Dailey, E. C.

Trout and R. S. BoYd

MCHARDY, G. J. R., and

D. S. PARSONS

Ross, E. J., and

A. G. SPENCER

Spencer, A. G., E. J. Ross 1954 Brit. med. J., 603-606. and H. G. L. LLOYD-

THOMAS

Visscher, M. B., R. R. 1945 Amer. J. Physiol. 144, 456-463.

ROEPKE and N. LIFSON

VISSCHER, M. B., and R. R. ROEPKE

WEERDEN, E. J. VAN

1945 Amer. J. Physiol. 144, 468-476.

1959 Over de osmotische waarde en de gehalten aan enige opgeloste bestanddelen van de darminhoud en de mest bij het rund, in verband gebracht met de resorptie der mineralen. Thesis, Wageningen.

1961 J. Agric. Sci. 56, p. 317. 